\title{
PENYEBAB TINGGINYA KARIES GIGI PADA WANITA USIA 15 - 44 TAHUN DI DESA GONDOSARI WILAYAH KERJA PUSKESMAS GONDOSARI KABUPATEN KUDUS
}

\author{
Rizki Fitriana Noor ${ }^{1}$, Ani Subekti ${ }^{\circledR 2}$, Yodong ${ }^{3}$, Bambang Sutomo ${ }^{4}$
}

\begin{abstract}
ABSTRAK
Karies merupakan suatu penyakit jaringan keras gigi yang disebabkan oleh aktivitas suatu jasad renik dalam suatu karbohidrat yang diragikan. Tanda-tandanya adalah adanya demineralisasi jaringan keras gigi yang diikuti kerusakan material organik. Karies disebabkan oleh faktor dari dalam dan faktor dari luar. Wanita pada umumnya lebih rentan terhadap masalah kesehatan gigi karena adanya perubahan hormonal yang mereka alami. Perubahan hormonal tersebut mempengaruhi aliran darah ke jaringan gusi dan juga mempengaruhi respons tubuh terhadap toksin yang dihasilkan oleh plak dan bakteri (mikroorganisme) sehingga menyebabkan timbulnya karies.

Jenis penelitian ini adalah deskriptif dengan rancangan penelitian berbentuk Cross Sectional yaitu melakukan pengukuran atau pengamatan dengan sampel 83 wanita usia 15 - 44 tahun di Desa Gondosari. Pengambilan data dilakukan dengan cara pemeriksaan langsung kepada wanita mengenai pH saliva, viskositas saliva, dan hidrasi saliva serta pemberian kuesioner yang meliputi faktor lingkungan, perilaku, pelayanan kesehatan dan keturunan. Data yang diperoleh dianalisa secara analitik deskriptif kuantitatif dan diprioritaskan menggunakan metode USG.

Faktor hidrasi saliva merupakan faktor dari dalam penyebab terjadinya karies yang paling dominan yaitu sebesar 79\%, diikuti pH Saliva dan viskositas Saliva. Sedangkan faktor perilaku merupakan faktor dari luar penyebab terjadinya karies paling dominan, diikuti lingkungan, pelayanan kesehatan dan keturunan. Disarankan mencari informasi tentang kesehatan gigi dan mulut serta meningkatkan kepedulian dan kesadaran, memperhatikan perilaku sosial, mengikuti penyuluhan, dan memperhatikan kesehatan gigi dan mulutnya dengan memeriksakan kesehatan gigi dan mulutnya secara rutin setiap 6 bulan sekali dan melakukan penambalan pada gigi yang berlubang.
\end{abstract}

Kata Kunci : Penyebab Karies, Wanita Usia 15-44 Tahun

\begin{abstract}
Caries is a disease of hard dental tissue caused by the activity of a microorganism in a carbohydrate that is fermented. The signs are the demineralization of dental hard tissue damage followed by organic material. Caries are caused by factors inside and outside factors. Women are generally more susceptible to dental problems because of hormonal changes they experience. Hormonal changes that affect blood flow to the gum tissue and also affect the body's response to toxins produced by plaque and bacteria (microorganisms) that cause caries.

This research is a descriptive cross sectional study design form that take measurements or observations with the sample 83 women aged 15-44 years in the village of Gondosari. Data collection was performed by means of direct examination to women regarding salivary $p H$, viscosity of saliva, and saliva hydration and administration of questionnaires that include environmental factors, behavior, health care and offspring. The data obtained were analyzed by quantitative descriptive analytic and prioritized using ultrasound.

Saliva hydration factor is a factor of the cause of dental caries is the most dominant at 79\%, followed by saliva $\mathrm{pH}$ and viscosity of saliva. While behavioral factors are external factors, the most dominant cause of dental caries, followed by the environment, health and heredity. Suggested searching for information about oral health and increase awareness and consciousness, attention to social behavior, following the extension, and pay attention to the health of teeth and mouth with healthy teeth and mouth checked regularly every six months and do fillings in cavities.
\end{abstract}

Keywords : Causes of caries, Women Age 15-44 Years

1) Perawat Gigi di Klinik Gigi Kudus

2,3,4) Dosen Prodi DIV Keperawatan Gigi Poltekkes Kemenkes Semarang

$\bowtie$ : anipurwanto@gmail.com 


\section{PENDAHULUAN}

Penyakit gigi yang paling banyak dikeluhkan masyarakat saat ini adalah karies. Karies merupakan suatu penyakit jaringan keras gigi, yaitu email, dentin, dan sementum, yang disebabkan oleh aktivitas suatu jasad renik dalam suatu karbohidrat yang diragikan. Tandanya adalah adanya demineralisasi jaringan keras gigi yang kemudian diikuti kerusakan bahan organiknya. Faktor utama penyebab terjadinya karies adalah gigi dan air ludah, mikroorganisme penyebab karies, substrat (makanan) serta waktu sebagai faktor tambahan. (Kidd, dkk, 1991). Karies gigi disebabkan oleh bakteri (mikroorganisme) yang mengubah makanan menjadi asam melalui proses fermentasi. Bakteri (mikroorganisme) dalam proses terjadinya karies sangat besar pengaruhnya, dimana mikroorganisme yang ada di dalam plak merupakan senyawa yang penting dalam pembentukan asam kuat yang dapat merusak lapisan terluar dan terkeras dari gigi yaitu email. Asam terus diproduksi oleh bakteri dan akhirnya merusak struktur gigi sedikit demi sedikit (Pratiwi, 2007).

Struktur email sangat menentukan proses terjadinya karies. Untuk menjaga kekerasan email sangat membutuhkan ion kimia yang disebut fluor. Umumnya sumber asupan utama fluor adalah air minum. Tingkat fluor yang rendah dapat meningkatkan kemungkinan karies gigi. WHO dan Depkes telah menetapkan 1,5 $\mathrm{mg} / \mathrm{L}$ sebagai konsentrasi maksimum fluor dalam air minum. WHO juga merekomendasikan tingkat $1 \mathrm{mg} / \mathrm{L}$ fluor dalam air minum untuk mencegah karies gigi dan nilai $0,5 \mathrm{mg} / \mathrm{L}$ sebagai konsentrasi minimum. Di Kecamatan Gebog Kabupaten Kudus konsentrasi fluor dalam air minum dengan nilai konsentrasi rata-rata fluor dari sampel air minum berkisar diantara 0,205$0,303 \mathrm{mg} / \mathrm{L}$ yaitu lebih rendah dari nilai yang direkomendasikan (1 $\mathrm{mg} / \mathrm{L})$. Efek yang sangat bermanfaat dari fluor ditemukan karena gigi-gigi penduduk di daerah geografis tertentu ternyata mengalami kerusakan gigi lebih sedikit dibanding daerah lainnya. Orang-orang yang suplai air minumnya mengandung kadar fluor alami sebanyak 1 ppm, memiliki kerusakan gigi setengahnya saja dibanding mereka yang mengkonsumsi air tanpa fluor.

Hasil Riset Kesehatan Dasar (RISKESDAS, 2007) Jawa Tengah menunjukan penduduk yang mempunyai pengalaman karies sebesar 67,8\% sedangkan yang tidak mempunyai pengalaman karies sebesar 32,2\% dan untuk prevalensi karies aktif sebesar $43,1 \%$. Sementara status kesehatan gigi dan mulut (DMF-T) sebesar $5,4 \%$ yang terdiri dari $\mathrm{D}: 1,2 \%, \mathrm{M}: 4,1 \%$ dan F:0,1\%. Untuk masyarakat yang melakukan sikat gigi dengan baik dan benar sebesar $4,5 \%$ dan yang tidak melakukan sikat gigi dengan baik dan benar sebesar 95,5\%. Sedangkan di Kabupaten Kudus menunjukkan penduduk yang mempunyai pengalaman karies sebesar 48,8\% serta yang tidak mempunyai pengalaman karies sebesar $51,2 \%$ dan untuk prevalensi karies aktif sebesar 27,4\%. Sementara status kesehatan gigi dan mulut (DMF-T) sebesar 2,5\% yang terdiri dari $\mathrm{D}: 0,6 \%, \mathrm{M}: 1,8 \%$ dan $\mathrm{F}: 0,0 \%$. Masyarakat yang melakukan sikat gigi dengan baik dan benar sebesar 3,2\% dan yang tidak melakukan sikat gigi dengan baik dan benar sebesar $6,8 \%$.

Penyakit gigi dan mulut yang paling banyak ditemukan di masyarakat adalah penyakit karies terutama pada kalangan wanita fase pubertas, siklus menstruasi, produktif, dan pramenopause (usia 15-44 tahun) (Alya, 2009). Berdasarkan data Puskesmas Gondosari Desa Gondosari Kabupaten Kudus, didapatkan data kesehatan gigi dan mulut pada tahun 2012 dengan data tingginya angka karies pada kelompok wanita yang rentan terserang karies yaitu usia 15-44 tahun mencapai rata-rata 73,85\%. Tujuan penelitian untuk mengetahui faktorfaktor penyebab tingginya angka karies gigi pada wanita usia 15-44 tahun di Desa Gondosari Wilayah Kerja Puskesmas 
Gondosari Kecamatan Gebog Kabupaten Kudus

\section{METODE PENELITIAN}

Jenis penelitian ini adalah deskriptif, dengan rancangan yang berbentuk Cross Sectional. Dari data profil puskesmas tahun 2012 jumlah wanita usia 15-44 tahun yang menderita karies di desa Gondosari wilayah kerja Puskesmas Gondosari Kota Kudus sebanyak 429 orang. Besar sampel yang diambil pada kelompok wanita usia 15-44 tahun di desa Gondosari wilayah kerja Puskesmas Gondosari adalah 81 orang. Teknik sampling yang digunakan adalah "Propotional Random Sampling" dimana peneliti dalam mengambil sampel dari tiaptiap RT disesuaikan dengan jumlah warga.

Variabel pengaruh penelitian ini adalah pH Saliva, Viskositas Saliva, Hidrasi Saliva, Lingkungan, Perilaku, Pelayanan Kesehatan dan Keturunan. Adapun variabel terpengaruhnya adalah angka karies gigi. Data yang diperoleh berupa data primer yaitu pemeriksaan saliva dan pengisian kuesioner. Data sekunder diambil dari data yang ada di Puskesmas Gondosari berdasarkan data jumlah penderita karies tertinggi yaitu wanita usia 15 - 44 tahun.

Uji validitas dilakukan pada setiap butir pertanyaan, kemudian melakukan korelasi antar skor masing-masing pertanyaan dengan skor total. Teknik korelasi yang digunakan adalah korelasi Pearson Product Momen. Uji reliabilitas dilakukan setelah pemeriksaan validitas dan semua pertanyaan menunjukkan valid. Uji reliabilitas dapat dilakukan secara bersamasama terhadap seluruh butir pertanyaan.

\section{HASIL DAN PEMBAHASAN}

1. Deskripsi Faktor-Faktor dari Dalam Penyebab Karies Gigi pada Wanita Usia 15 - 44 Tahun di Desa Gondosari a. Hasil Pemeriksaan pH Saliva Pada Responden

Tabel 1. Hasil Pemeriksaan pH Saliva pada Wanita Usia 15-44 Tahun di Desa Gondosari

\begin{tabular}{cccc}
\hline Kondisi & Kriteria & Frekuensi & Prosentase \\
\hline $5,0-5,8$ & Asam & 45 & $56 \%$ \\
\hline $6,0-6,6$ & Netral & 18 & $22 \%$ \\
\hline $6,8-7,8$ & Basa & 18 & $22 \%$ \\
\hline Jumlah & 81 & $100 \%$ \\
\hline
\end{tabular}

Berdasarkan tabel 1 menunjukkan hasil pemeriksaan $\mathrm{pH}$ saliva pada 81 responden menunjukkan bahwa 45 responden $(56 \%)$ memiliki saliva yang asam, 18 responden (22\%) memiliki saliva yang netral dan sisanya 18 responden $(22 \%)$ memiliki saliva yang sifatnya basa.

b. Hasil Pemeriksaan Viskositas Saliva Pada Responden

Tabel 2. Hasil Pemeriksaan Visikositas Saliva pada Wanita Usia 15-44 Tahun di Desa Gondosari

\begin{tabular}{cccc}
\hline Viskositas & Kriteria & Frekuensi & Prosentase \\
\hline $\begin{array}{c}\text { Saliva seperti } \\
\text { air jernih }\end{array}$ & Baik & 5 & $6 \%$ \\
\hline $\begin{array}{c}\text { Saliva berbusa } \\
\text { bergelembung }\end{array}$ & Sedang & 44 & $54 \%$ \\
\hline $\begin{array}{c}\text { Saliva sangat lengket } \\
\text { bergelembung }\end{array}$ & Tinggi & 32 & $40 \%$ \\
\hline Jumlah & & 81 & $100 \%$ \\
\hline
\end{tabular}

$\begin{array}{ccr}\text { Berdasarkan } & \text { Tabel } & 2 \\ \text { menunjukkan } & \text { hasil } & \text { pemeriksaan }\end{array}$ viskositas saliva pada 81 responden menunjukkan bahwa viskositas saliva tertinggi terdapat pada kriteria sedang dengan keadaan viskositas saliva berbusa bergelembung sebanyak 44 responden $(54 \%)$. Kriteria tinggi dengan keadaan viskositas saliva sangat lengket dan bergelembung sebanyak 32 responden (40\%). Dan kriteria normal dengan keadaan viskositas saliva seperti air jernih sebanyak 5 responden $(6 \%)$. 
c. Hasil Pemeriksaan Hidrasi Saliva Pada Responden

Tabel 3. Hasil pemeriksaan Hidrasi Saliva pada Wanita Usia 15 - 44 Tahun di Desa Gondosari

\begin{tabular}{cccc}
\hline Skor & Kriteria & Frekuensi & Prosentase \\
\hline$>60$ detik & Rendah & 64 & $79 \%$ \\
\hline$<60$ detik & Normal & 17 & $20 \%$ \\
\hline Jumlah & 81 & $100 \%$
\end{tabular}

Berdasarkan Tabel 3
menunjukkan hasil pemeriksaan hidrasi saliva pada 81 responden menunjukkan bahwa 64 responden $(79 \%)$ memiliki saliva yang rendah dan yang memiliki saliva yang normal sebanyak 17 responden $(21 \%)$.

2. Distribusi Pemeriksaan Faktor Dari Luar Penyebab Karies Gigi pada Wanita Usia 15 - 44 Tahun di Desa Gondosari

a. Faktor Lingkungan

Tabel 4. Hasil Penilaian Kuisioner Faktor Lingkungan pada Wanita Usia 15-44 Tahun di Desa Gondosari

\begin{tabular}{ccc}
\hline Kriteria & Frekuensi & Prosentase \\
\hline Baik & 15 & $19 \%$ \\
\hline Cukup & 58 & $71 \%$ \\
\hline Kurang & 8 & $10 \%$ \\
\hline Jumlah & 81 & $100 \%$ \\
\hline
\end{tabular}

Berdasarkan tabel 4 diatas yaitu hasil penilaian kuisioner mengenai faktor lingkungan pada wanita usia $15-44$ tahun di Desa Gondosari menunjukkan bahwa faktor lingkungan di Desa Gondosari sudah cukup baik dengan kriteria cukup sebanyak 58 responden (71\%) yaitu masyarakat masih mempunyai waktu untuk periksa gigi, diikuti dengan kriteria baik sebanyak 15 responden (19\%) yaitu masyarakat mudah mendapat air minum dan memiliki sikat gigi sendiri-sendiri, dan kriteria kurang sebanyak 8 responden $(10 \%)$ yaitu masyarakat kurang mendapat informasi tentang kesehatan gigi dan mulut di tempat tinggalnya.

\section{b. Faktor Perilaku}

Tabel 5. Hasil Penilaian Kuisioner Faktor Perilaku pada Wanita Usia 15-44 Tahun di Desa Gondosari

\begin{tabular}{ccc}
\hline Kriteria & Frekuensi & Prosentase \\
\hline Baik & 13 & $16 \%$ \\
\hline Cukup & 59 & $73 \%$ \\
\hline Kurang & 9 & $11 \%$ \\
\hline Jumlah & 81 & $100 \%$ \\
\hline
\end{tabular}

Berdasarkan Tabel 5 diatas yaitu hasil penilaian kuisioner mengenai faktor perilaku pada wanita usia 15 - 44 tahun di Desa Gondosari menunjukkan bahwa faktor perilaku di Desa Gondosari sudah cukup baik dengan kriteria cukup sebanyak 59 responden $(73 \%)$ yaitu masyarakat setiap hari menggosok gigi, diikuti dengan kriteria baik sebanyak 13 responden $(16 \%)$ yaitu masyarakat menggosok gigi dengan pasta gigi, dan kriteria kurang sebanyak 9 responden $(11 \%)$ yaitu masyarakat yang tidak selalu berkumur air putih setelah makan makanan manis dan melekat.

\section{c. Faktor Pelayanan Kesehatan}

Tabel 6. Hasil Penilaian Kuisioner Faktor Pelayanan Kesehatan pada Wanita Usia 15 - 44 Tahun di Desa Gondosari

\begin{tabular}{ccc}
\hline Kriteria & Frekuensi & Prosentase \\
\hline Baik & 12 & $14 \%$ \\
\hline Cukup & 55 & $68 \%$ \\
\hline Kurang & 14 & $18 \%$ \\
\hline Jumlah & 81 & $100 \%$ \\
\hline
\end{tabular}

Berdasarkan Tabel 6 diatas yaitu hasil penilaian kuisioner mengenai faktor pelayanan kesehatan pada wanita usia 15 44 tahun di Desa Gondosari menunjukkan bahwa faktor pelayanan kesehatan di Desa Gondosari sudah cukup baik dengan kriteria cukup sebanyak 56 responden $(67 \%)$ yaitu petugas tenaga kesehatan ramah, diikuti dengan kriteria kurang sebanyak 15 responden (18\%) yaitu masyarakat kurang mendapat informasi 
tentang sarana pelayanan kesehatan gigi dan mulut, dan kriteria baik sebanyak 12 responden (14\%) lokasi sarana pelayanan kesehatan mudah dijangkau.

\section{d. Faktor Keturunan}

Tabel 7. Hasil Penilaian Kuisioner Faktor Keturunan pada Wanita Usia 15 - 44 Tahun di Desa Gondosari

\begin{tabular}{ccc}
\hline Kriteria & Frekuensi & Prosentase \\
\hline Baik & 12 & $14 \%$ \\
\hline Cukup & 48 & $60 \%$ \\
\hline Kurang & 21 & $25 \%$ \\
\hline Jumlah & 81 & $100 \%$ \\
\hline
\end{tabular}

Berdasarkan Tabel 7 diatas yaitu hasil penilaian kuisioner mengenai faktor keturunan pada wanita usia 15 - 44 tahun di Desa Gondosari menunjukkan bahwa faktor keturunan di Desa Gondosari sudah cukup baik dengan kriteria cukup sebanyak 48 responden (59\%) yaitu tidak banyak masyarakat mempunyai gigi linu, diikuti dengan kriteria kurang sebanyak 21 responden (26\%) yaitu cukup banyak masyarakat yang mempunyai karang gigi dalam giginya, dan kriteria baik sebanyak 12 responden $(15 \%)$ yaitu masih banyak masyarakat yang mempunyai susunan gigi yang rapi dan tidak renggang atau berjejal.

Berdasarkan hasil pemeriksaaan dan hasil kuesioner dari 81 wanita Usia $15-44$ Tahun di Desa Gondosari Kecamatan Gebog Kabupaten Kudus diketahui bahwa semua sampel yang diperiksa berpotensi menimbulkan karies gigi dan didapatkan faktor penyebab terjadinya karies baik dari dalam dalam rongga mulut dan faktor dari luar rongga mulut.

\section{A. Faktor Penyebab dari Dalam}

1. pH Saliva

Karies dapat dipengaruhi oleh derajat keasaman saliva. Hasil penelitian pada Wanita Usia 15-44 tahun di Desa Gondosari menunjukkan bahwa sebagian besar responden mempunyai $\mathrm{pH}$ saliva yang asam sebesar $57 \%$. Hal ini terlihat dari rekapitulasi dimana kebiasaan makan makanan manis dan melekat yang tidak segera minum air putih sebesar $73 \%$. $p H$ saliva yang bersifat asam lebih mudah menyebabkan karies sedangkan $p H$ saliva yang bersifat basa lebih mudah menyebabkan calculus atau karang gigi. Menurunnya $\mathrm{pH}$ saliva menunjukkan adanya resiko terjadinya karies yang tinggi. Proses demineralisasi jaringan keras gigi (email) pada penurunan $\mathrm{pH}$ saliva $(\mathrm{pH}$ saliva asam) akan lebih cepat meningkat. Apabila $\mathrm{pH}$ saliva mencapai $\mathrm{pH}$ kritis akan menyebabkan terjadinya proses demineralisasi jaringan keras gigi. Seseorang yang mempunyai banyak karies akan mempunyai $\mathrm{pH}$ saliva yang rendah. Proses karies gigi adalah sisa makanan yang menempel pada permukaan gigi (plak) bila dibiarkan lama akan diubah oleh bakteri dalam mulut menjadi asam, zat asam ini akan merapuhkan (demineralisasi) email sehingga akan terjadi karies.

\section{Viskositas Saliva}

Karies dapat dipengaruhi oleh viskositas saliva yaitu konsistensi saliva ketika istirahat atau keadaan saliva. Hasil penelitian pada Wanita Usia 15 - 44 tahun di Desa Gondosari menunjukkan bahwa sebagian besar responden mempunyai viskositas saliva sedang sebesar 45 responden (54\%) dengan keadaan saliva berbusa dan bergelembung, diikuti dengan viskositas tinggi sebesar 33 responden (40\%) dengan keadaan saliva sangat lengket dan bergelembung. Dari skor tersebut menunjukkan bahwa semakin tinggi viskositas saliva seseorang maka semakin tinggi pula resiko terjadinya karies pada gigi.

\section{Hidrasi Saliva}

Karies dapat dipengaruhi oleh hidrasi saliva yaitu laju aliran saliva. Hasil penelitian pada Wanita Usia 15 - 44 tahun di Desa Gondosari menunjukkan bahwa sebagian besar responden mempunyai viskositas saliva rendah sebesar 66 
responden $(80 \%)$ dengan laju aliran saliva > 60 detik. Faktor yang dapat mempengaruhi kecepatan aliran saliva saat terstimulasi adalah asal stimulus, pengunyahan, muntah, merokok, ukuran kelenjar saliva, indera penciuman dan pengecapan, asupan makanan, faktor emosi-psikis, dan usia. Hal ini terlihat dari rekapitulasi hasil pemeriksaan kecepatan aliran saliva dan hasil kuesioner yaitu pada asupan makanan dengan kebiasaan masyarakat yang tidak segera minum air putih $73 \%$ dan pada faktor kebiasaan masyaraat yang tidak menyikat gigi sebelum tidur malam $70 \%$. Hidrasi saliva yang rendah bisa menyebabkan penurunan produksi saliva didalam mulut sehingga akan mengakibatkan mukosa oral kering, kasar dan lengket, mudah berdarah dan mudah terjadi infeksi. Lidah menjadi merah, halus, lemah, hipersensitif terhadap iritasi serta kehilangan ketajaman pengecapan. Akan terdapat akumulasi plak, material alba dan debris yang parah sehingga akan menimbulkan penyakit karies.

\section{B. Faktor Penyebab dari Luar \\ 1. Lingkungan}

Dari hasil penilaian kuisioner didapatkan hasil bahwa responden yang mengkonsumsi air minum dari sumur sebanyak 51 responden (63\%), mengetahui air minum yang dikonsumsi mengandung fluor sebanyak 14 responden (17\%), dan mudah mendapatkan air bersih sebanyak 75 responden (93\%). Hal ini menunjukkan akses mendapatkan air minum di Desa Gondosari mudah sehingga masyarakat dapat dengan bebas menggunakannya.

Responden yang sudah memiliki sikat gigi pribadi sebanyak 75 responden (93\%), mengingatkan anggota keluarga untuk menyikat gigi sebanyak 29 responden $(31 \%)$, terkait aktivitas sehingga tidak ada waktu untuk memeriksakan atau mendapat perawatan gigi sebanyak 62 responden (77\%), memberikan informasi kesehatan gigi dan mulut kepada saudara sebanyak 34 responden (42\%), keadaan lingkungan yang peduli terhadap kesehatan gigi dan mulut sebanyak 24 responden (30\%), dan keluarga yang memiliki sikat gigi untuk bersama sebanyak 61 responden $(75 \%)$. Hal ini menunjukkan masyarakat cukup peduli terhadap kesehatan gigi dan mulut dalam kehidupan sehari-hari yaitu dengan banyak masyarakat yang menggunakan sikat gigi sendiri tetapi tingkat aktifitas yang tinggi juga menjadi penyebab masyarakat mengabaikan perawatan gigi.

Responden yang pernah mendapatkan informasi kesehatan gigi dan mulut oleh tenaga kesehatan sebanyak 20 responden (25\%). Hal ini menunjukkan kurangnya informasi kesehatan gigi dan mulut yang didapatkan oleh masyarakat di lingkungan tempat tinggalnya sehingga menyebabkan kepedulian masyarakat akan kesehatan gigi dan mulutnya menjadi rendah.

\section{Perilaku}

Dari hasil penilaian kuisioner didapatkan hasil bahwa responden yang setiap hari menyikat gigi sebanyak 75 responden (93\%), menyikat gigi sebelum tidur sebanyak 24 responden $(30 \%)$, menyikat gigi dengan pasta gigi sebanyak 77 responden (95\%), dan mengetahui pasta gigi yang digunakan mengandung fluor sebanyak 55 responden $(68 \%)$. Hal ini menunjukkan masyarakat sudah mengetahui tentang kegiatan menyikat gigi. Perilaku menyikat gigi sangat berpengaruh terhadap kebersihan gigi seseorang Frekuensi menyikat gigi minimal 2 kali sehari yaitu setelah makan pagi dan sebelum tidur malam. Menyikat gigi sebelum tidur sangatlah penting. Aktivitas kuman di malam hari biasanya akan meningkat 2 kali lipat dibandingkan pada siang hari, karena saat tidur di mana mulut kita tidak melakukan aktivitas seperti makan, minum, atau berbicara, air liur yang memang berfungsi sebagai antiseptik alami dalam mulut kita akan berkurang, sehingga kemampuan saliva 
yang berfungsi untuk menetralisir kumankuman dalam mulut juga berkurang. Dan sebanyak apapun kuman dalam mulut, bila kita sudah menyikat gigi dan kondisi mulut kita bersih dapat dipastikan tidak akan terjadi karies. Responden setelah makan makanan manis melekat atau ngemil selalu minum atau berkumur air putih sebanyak 22 responden (27\%), mengetahui makanan manis melekat atau ngemil yang tidak dibersihkan dapat menyebabkan gigi berlubang sebanyak 34 responden (42\%), mengetahui bahwa buah-buahan dapat membantu membersihkan sisa makanan yang menempel pada gigi sebanyak 31 responden (38\%), dan mengetahui penyebab gigi berlubang sebanyak 31 respnden $(38 \%)$. Hal ini menunjukkan pegetahuan dan perilaku sosial masyarakat terhadap makanan yang mereka konsumsi masih rendah sehingga menyebabkan tingginya karies gigi.

Responden bila sakit gigi berobat ke puskesmas atau lembaga pelayanan gigi dan mulut sebanyak 56 responden (69\%). Hal ini menunjukkan perilaku kesadaran masyarakat akan pemeliharaan dan perawatan masyarakat akan kesehatan gigi dan mulut sudah cukup tetapi perlu adanya peningkatan.

Responden yang mengganti sikat gigi setiap 6 bulan sekali sebanyak 15 responden (19\%). Hal ini menunjukkan sangat rendahnya kesadaran masyarakat tentang pemeliharaan atas dampak yang perilaku yang seharusnya mereka lakukan tetapi masih terabaikan. Kebiasaan pemeliharaan kesehatan gigi dan mulut yang buruk seperti penggantian sikat gigi ketika sudah rusak masih sangat sangat rendah sehingga menurunkan kebersihan gigi.

\section{Pelayanan Kesehatan}

Dari hasil penilaian kuisioner didapatkan hasil bahwa responden yang mengetahui di sarana pelayanan kesehatan terdapat sarana pelayanan kesehatan gigi sebanyak 67 responden (83\%). Hal ini menunjukkan kepedulian masyarakat terhadap sarana pelayanan kesehatan sudah cukup baik tetapi harus ditingkatkan agar semakin banyak yang mengetahui sarana kesehatan maka semakin banyak pula yang melakukan pemeriksanaan kesehatan gigi dan mulut.

Responden yang mendapatkan informasi tantang kesehatan gigi dan mulut oleh tenaga kesehatan gigi di sarana pelayanan kesehatan sebanyak 33 responden (41\%) kurangnya informasi tentang sarana pelayanan kesehatan gigi masih rendah padahal penyuluhan kesehatan gigi dan mulut pada masyarakat merupakan hal yang sangat penting karena dapat menambah informasi untuk meningkatkan pengetahuan masyarakat tentang kesehatan gigi dan mulut, sehingga masyarakat sadar akan pentingnya memelihara kesehatan gigi dan mulut dan melakukan perawatan gigi dan mulut di sarana pelayanan kesehatan.

Responden yang mendapatkan pelayanan kesehatan gigi dan mulut di sarana pelayanan kesehatan sebanyak 64 responden (79\%), melakukan pemeriksaan gigi di sarana pelayanan kesehatan sebanyak 64 responden (79\%), dan mendapat perawatan gigi berlubang sebanyak 37 responden (46\%). Hal ini menunjukkan kesadaran masyarakat akan kesehatan gigi dan mulutnya sudah baik dengan mendapatkan pelayanan dilanjutkan dengan pemeriksaan gigi dan mulut dan melakukan perawatan gigi berlubang.

Penilaian responden terhadap sarana pelayanan kesehatan meliputi ruang pelayanan kesehatan gigi bersih dan nyaman sebanyak 69 responden $(85 \%)$, petugas pelayanan kesehatan gigi dalam memberikan pelayanan gigi sudah tepat sebanyak 65 responden (80\%), petugas pelayanan kesehatan ramah sebanyak 73 responden $(90 \%)$, terdapat transportasi menuju tempat pelayanan kesehatan sebanyak 72 responden (89\%), dan biaya 
pelayanan kesehatan gigi yang dapat dijangkau sebanyak 74 responden (12\%). Hal ini menunjukkan sudah baiknya sarana dan prasarana pada sarana pelayanan kesehatan. Suatu pelayanan kesehatan yang bermutu adalah apabila pelayanan kesehatan tersebut dapat dicapai oleh pemakai jasa pelayanan kesehatan. Kondisi tempat pelayanan yang dapat dijangkau dari tempat tinggal dan mudahnya akses transportasi untuk menuju ke tempat pelayanan kesehatan membuat masyarakat dapat dengan mudah untuk datang berobat ke tempat pelayanan kesehatan.

\section{Keturunan}

Dari hasil penilaian kuisioner didapatkan hasil bahwa responden dengan susunan gigi renggang atau berjejal sebanyak 34 responden (42\%), kondisi susunan gigi renggang atau berjejal sama dengan anggota keluarga sebanyak 34 responden $(42 \%)$, susunan gigi rapi sebanyak 38 responden (47\%), mempunyai bentuk gigi besar sebanyak 50 responden (62\%), mempunyai bentuk gigi besar sama dengan keluarga sebanyak 49 responden $(60 \%)$, warna gigi sama dengan warna gigi keluarga sebanyak 64 responden $(79 \%)$, mempunyai karang gigi sebanyak 41 responden (51\%), mempunyai karang gigi sama dengan keluarga sebanyak 45 responden $(56 \%)$, mempunyai gigi sensitif sebanyak 40 responden (49\%), dan mempunyai gigi sensitif sama dengan keluarga sebanyak 48 responden $(59 \%)$.

\section{KESIMPULAN}

1. Hasil pemeriksaan faktor dari dalam penyebab tingginya karies gigi pada wanita usia $15 \quad 44$ tahun di Desa Gondosari adalah sebagai berikut :

a. $\mathrm{pH}$ saliva yang menjadi faktor penyebab tingginya karies gigi adalah $\mathrm{pH}$ saliva asam dengan kondisi 5,0 -
5,8 sebesar $57 \%$, diikuti $\mathrm{pH}$ saliva netral dengan kondisi 6,0 - 6,6 sebesar $22 \%$, dan $\mathrm{pH}$ saliva basa dengan kondisi 6,8 - 7,8 sebesar $22 \%$.

b. Viskositas saliva yang menjadi faktor penyebab tingginya karies gigi adalah viskositas sedang dengan kondisi saliva berbusa dan bergelembung sebesar $54 \%$, diikuti viskositas saliva tinggi dengan kondisi sangat lengket dan bergelembung sebesar $40 \%$, dan viskositas normal dengan kondisi seperti air jernih hanya $6 \%$.

c. Hidrasi saliva yang menjadi faktor penyebab tingginya karies gigi adalah hidrasi rendah dengan kondisi laju aliran saliva $>60$ detik sebesar $80 \%$ dan hidrasi normal dengan kondisi laju aliran saliva $<60$ detik hanya $20 \%$.

2. Hasil penilaian faktor dari luar penyebab tingginya karies gigi pada wanita usia 15 44 tahun di Desa Gondosari adalah sebagai berikut :

a. Faktor lingkungan yang menjadi faktor penyebab tingginya karies gigi adalah masyarakat kurang mendapatkan informasi tentang kesehatan gigi dan mulut di lingkungan tempat tinggalnya, disertai dengan rendahnya kepedulian masyarakat terhadap kesehatan gigi dan mulut.

b. Faktor perilaku yang menjadi faktor penyebab tingginya karies gigi adalah masyarakat sering mengkonsumsi makanan manis dan melekat tetapi tidak segera berkumur atau minum air.

c. Faktor pelayanan kesehatan yang menjadi faktor penyebab tingginya karies gigi adalah masyarakat kurang mendapatkan informasi atau penyuluhan tentang sarana kesehatan gigi dan mulut dari tenaga kesehatan dan kurangnya antusias masyarakat untuk mempertahankan giginya dengan menambal gigi yang berlubang.

d. Faktor keturunan yang menjadi faktor penyebab tingginya karies gigi adalah susunan gigi masyarakat yang 
renggang atau berjejal sehingga menurun pada anaknya.

\section{DAFTAR PUSTAKA}

Anonim $^{1}, \quad 2013, \quad$ Karies Gigi, http://utamadental.wordpress.com/201 1/03/03/karies-gigi/akses 15 Januari $\underline{2013}$

Anonim $^{2}$, 2012 , Saliva, http://potooloodental.blog.com/?p=49 $\underline{8}$ diakses 15 Januari 2012

Alya, N., 2009, Wanita dan Kesehatan Gigi, Last Update : 22 Maret 2009, http://thesmilecentre.multiply.com/jou rnal?\&show_interstitial $=1 \& u=\% 2$ Fjou rnal, diakses 15 Januari 2013

Amerongen, 1991, Ludah Dan Kelenjar Ludah Arti Bagi Kesehatan Gigi(Terj.), Gadjah Mada University Press, Yogyakarta

Depkes RI., 2009, UU Kesehatan No 36 Tahun 2009 : Jakarta

Hendari dan Siregar., 2012, Panduan Pengelolaan Kasus Kesehatan Gigi Dan Mulut Dan Penulisan Laporan Studi Kasus (Edisi 4), Politeknik Kesehatan Kemenkes Semarang, Semarang

Hurint, T., 2012, Kerusakan Gigi, Last Update : 22 Mei 2012, http://tessahurint.blogspot.com/2012/0 5/kerusakan-gigi.html, diakses 15 Januari 2012

Kidd dan Bechal., 1992, Dasar-dasar Karies Penyakit dan Penanggulangannya.

Machfoedz, I., Zein, A.Y., 2005, Menjaga Kesehatan Gigi Dan mulut Anak-anak dan Ibu Hamil, Fitramaya, Yogyakarta
Notoatmodjo, S $^{1}$., 2007. Promosi Kesehatan dan Ilmu Perilaku, Rineka Cipta, Jakarta

Notoatmodjo $^{2}, \quad 2010, \quad$ Ilmu Perilaku Kesehatan, Rineka Cipta, Jakarta

Pratiwi, D., 2007, Gigi Sehat Merawat Gigi Sehari-hari, PT Kompas Media Nusantara, Jakarta

Riset Kesehatan Dasar., 2007, Laporan Provinsi Jawa Tengah 2008, Badan Penelitian dan Pengembangan Kesehatan, Dep.Kes. RI Jakarta.

Suwelo., 1992, Karies Gigi pada Anak dengan Berbagai Faktor Etiologi : Kajian pada Anak Usia Pra sekolah, EGC, Jakarta

Suwelo., 1997, Karies pada anak dengan berbagai faktor etiologi, EGC, Jakarta

Tarigan, R., 1992. Karies Gigi, Hipokrates, Jakarta 